\title{
Possible dietary protective factors in relation to the distribution of duodenal ulcer in India and Bangladesh
}

\author{
A P JAYARAJ,* F I TOVEY,† AND C G CLARK \\ From the Central Food Technological Research Institute, Mysore, Basingstoke District Hospital, Basingstoke, \\ and University College Hospital Medical School, London
}

SUMMARY In India there are regions of high incidence and regions of low incidence of duodenal ulcer. Rats prefed for two weeks on diets from low incidence areas developed significantly fewer rumenal ulcers after pyloric ligation than rats fed on diets from high incidence areas. The protective action was found in various individual items of food taken from the diets of low incidence areas. Unrefined wheat and rice, certain pulses (black gram, green gram, horse gram), some millets (sava, kutki, ragi), soya bean, ladies' fingers, cabbage, spinach, and whole cream milk were protective. Refined wheat, polished rice, maize, cornflour, sorghum vulgare, sugar, bananas, amaranthus, brinjal, peanut oil, some pulses (Bengal gram, turdhal), and skimmed milk were non-protective. The protective factor seems to be either a lipid or a liposoluble substance which is active whether given orally or parenterally. Horse gram (Dolichos biflorus) is a particularly potent source.

The map in Fig. 1 shows the distribution of duodenal ulcer in India and Bangladesh. There are marked dietary differences between the areas of relatively high and low incidence. ${ }^{1}$ In the lower incidence areas of North India (Punjab, Rajasthan, and parts of Madhya Pradesh, Uttar Pradesh, Haryana, and Himachal Pradesh) the staple food is unrefined wheat eaten as chappatis. In many areas, particularly the Punjab, the diet of unrefined wheat is supplemented by considerably more milk or milk products, pulses, and green vegetables than are eaten in the areas of high incidence.

In almost all of the high incidence areas the staple diet is refined polished rice. This is supplemented in some of the areas, especially Kerala, by variable amounts of manioc (cassava or tapioca). In a relatively dry belt of higher incidence running horizontally eastwards across Maharashtra, Northern Karnataka into Andhra Pradesh, the staple diet is the millet sorghum vulgare (jowar or cholam) with occasional rice. In some drier areas, such as in the Aravalli hills of Rajasthan where duodenal ulcer is common, the staple diet is maize.

*Present address: Department of Surgery, University College Hospital Medical School, London.

†Address for reprint requests: Mr F I Tovey, 17 Priory Gardens, Old Basing. Hampshire.

Received for publication 19 June 1980
In addition to these broad differences in the distribution of duodenal ulcer there are interesting isolated areas of low incidence with peculiar dietary habits surrounded by rice eating areas of high incidence.

One such area is found in Orissa at Udaiyagiri where the Kond tribes living in the eastern ghats have a lower incidence of duodenal ulcer than the rice-eating Oriyas in the plains. The Kond's diet is seasonal, made up of a grass-like cereal called Kahari or Querry, the pulses Bengal gram and horse gram, mango seeds, jungle plants, and roots and mahula flowers.

Another area is that inhabited by the Gond tribes around Padhar in southern Madhya Pradesh. They use the millets sava (Echinochola freemantacea) and kutki (Faricum millare) cooked into chappatis.

A third area of relatively low incidence is found south of Mysore where for most of the year the staple diet is the millet ragi (Eleucine coracana). A low incidence is also reported in the drier hilly areas of Bihar where more millets and pulses are grown.

There are also isolated islands of high incidence surrounded by areas of low incidence. These islands have a moister climate and rice is grown as the staple food. Such areas occur around Simla and in the Kangra Hills, in Hoshiarpur, around Srinagar in Kashmir. and in the plains of Assam. 
Fig. 1 Map showing distribution of duodenal ulcer in India and Bangladesh. The areas of high incidence are stippled.

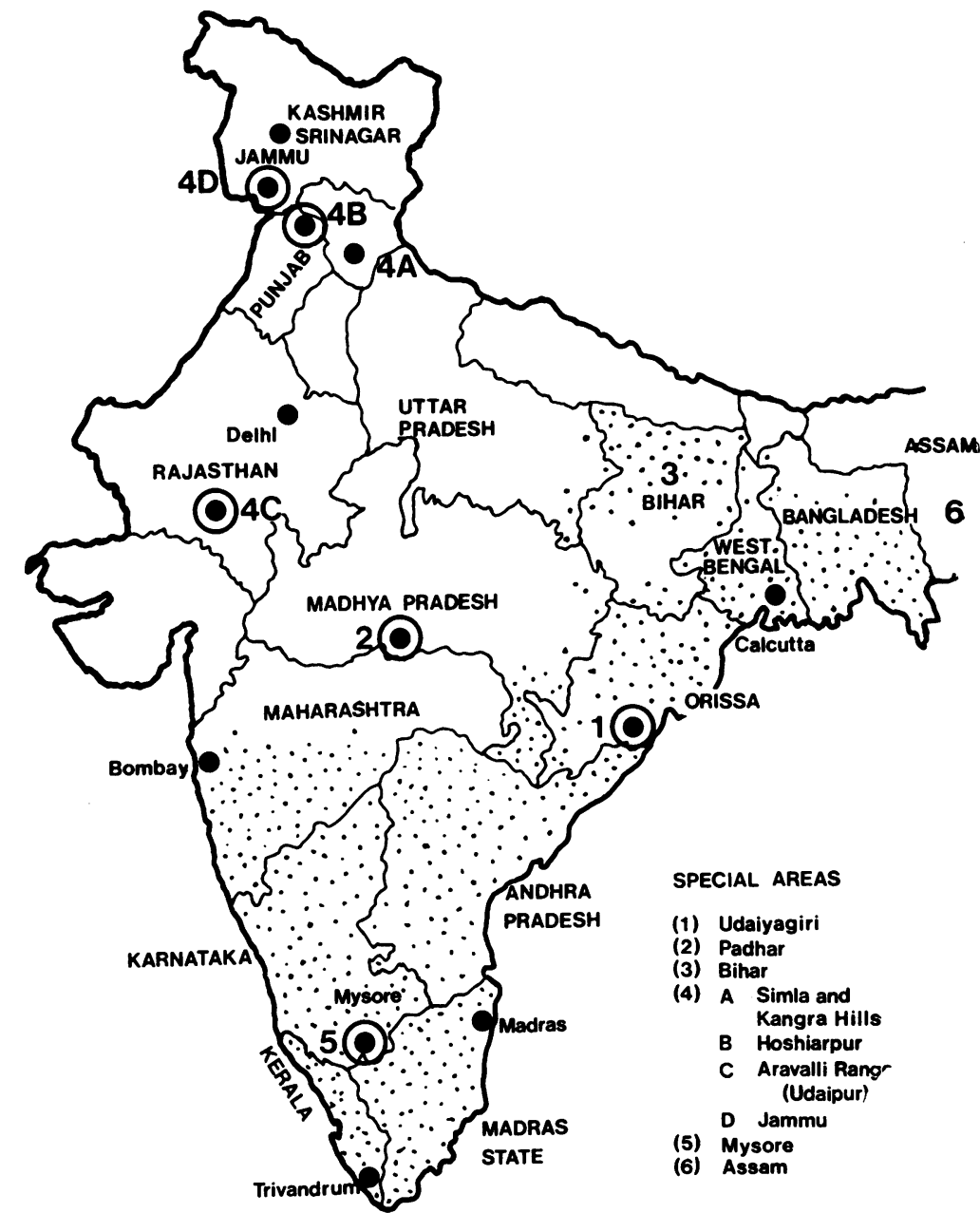

The possibility that differences in diet might be factors of aetiological importance contributing to the differences in incidence of duodenal ulcer is supported by the report of Malhotra ${ }^{2}$ in 1978 . He described a group of 50 patients in Bombay with radiologically proven duodenal ulcers who were hospitalised until their ulcers were symptomatically and radiologically healed. After this, one half continued on their normal rice diet and one half changed to a Punjabi diet. At the end of five years 21 patients were left in each group. Among those on the Punjabi diet only three $(13 \%)$ had relapsed in comparison with $17(81 \%)$ of those on their normal rice diet.

These findings would support either the concept that there may be ulcerogenic factors in the diet of high incidence areas or protective factors in the diet of low incidence areas.

\section{Methods}

PYLORUS LIGATION EXPERIMENTS

The pylorus ligated rat was chosen as an acceptable model for investigating these possibilities because it is one that has already been widely used in testing ulcerogenic or anti-ulcer substances. ${ }^{3}$ Female albino rats (Wistar strain), weighing $100-160 \mathrm{~g}$, in batches of eight were fed on the required food substances for a period of two weeks. They were then isolated in a wire meshed cage to avoid coprophagy and given water only for 24 hours. A pyloric ligation ${ }^{4}$ was then performed under ether anaesthesia. The stomach was washed out with $4 \mathrm{ml}$ or more of normal saline until clean and then $2 \mathrm{ml}$ of normal saline were left in the stomach. The rats were kept isolated and allowed access to water for six hours, at the end of which time they were again anaesthe- 
Table 1 Controls

\begin{tabular}{|c|c|c|c|c|c|c|}
\hline & \multirow{2}{*}{$\begin{array}{l}\text { Total no. } \\
\text { of rats }\end{array}$} & \multicolumn{5}{|l|}{ Rumenal ulcers } \\
\hline & & $\begin{array}{l}\text { No. of rats } \\
\text { with ulcers }\end{array}$ & $\begin{array}{l}\text { Total no. } \\
\text { of ulcers }\end{array}$ & Large ulcers & Perforations & Ulcer score \\
\hline $\begin{array}{l}\text { South Indian (cooked) } \\
\text { South Indian (uncooked) } \\
1 \\
2 \\
3 \\
4 \\
5 \\
6 \\
7 \\
8 \\
9 \\
10 \\
11 \\
12 \\
13 \\
14 \\
15 \\
16 \\
17 \\
18 \\
19 \\
\text { Total (uncooked) }\end{array}$ & $\begin{array}{r}8 \\
8 \\
8 \\
8 \\
8 \\
8 \\
8 \\
8 \\
8 \\
8 \\
8 \\
8 \\
8 \\
8 \\
8 \\
8 \\
8 \\
8 \\
8 \\
152\end{array}$ & $\begin{array}{l}8 \\
8 \\
8 \\
7 \\
7 \\
7 \\
8 \\
8 \\
8 \\
8 \\
8 \\
7 \\
8 \\
8 \\
7 \\
8 \\
8 \\
8 \\
7 \\
147 \\
\% \text { with ulcers } \\
96 \cdot 7 \%\end{array}$ & $\begin{array}{l}33 \\
35 \\
37 \\
25 \\
20 \\
27 \\
16 \\
11 \\
25 \\
17 \\
27 \\
30 \\
18 \\
20 \\
25 \\
38 \\
32 \\
23 \\
27 \\
491\end{array}$ & $\begin{array}{r}10 \\
9 \\
14 \\
9 \\
9 \\
6 \\
5 \\
6 \\
6 \\
5 \\
4 \\
4 \\
4 \\
5 \\
6 \\
12 \\
8 \\
12 \\
6 \\
140 \\
\% \text { of total ulcers } \\
28 \cdot 5 \%\end{array}$ & $\begin{array}{l}4 \\
5 \\
4 \\
4 \\
2 \\
5 \\
3 \\
2 \\
2 \\
2 \\
3 \\
2 \\
2 \\
2 \\
5 \\
3 \\
4 \\
3 \\
5 \\
60 \\
\% \text { of total rats } \\
39 \cdot 5 \%\end{array}$ & $\begin{array}{l}4 \cdot 25 \\
4 \cdot 1 \\
4 \cdot 4 \\
4 \cdot 6 \\
3 \cdot 1 \\
2 \cdot 5 \\
3 \cdot 4 \\
2 \cdot 0 \\
1 \cdot 375 \\
3 \cdot 1 \\
2 \cdot 1 \\
3 \cdot 4 \\
3 \cdot 75 \\
2 \cdot 25 \\
2 \cdot 5 \\
3 \cdot 1 \\
4 \cdot 75 \\
4 \cdot 0 \\
2 \cdot 9 \\
3 \cdot 4 \\
\\
\text { Mean ulcer score } \\
3 \cdot 2\end{array}$ \\
\hline
\end{tabular}

tised. The oseophagus was ligated and the stomach. with contents, was removed. The stomach was opened and the number of macroscopic ulcers in the rumen were recorded, together with the number of large ulcers $(>2 \mathrm{~mm})$ and the number of rats with perforations. Histological sections were made also of the rumen and mucosa.

For comparison an 'ulcer score', obtained by dividing the total number of ulcers by the number of rats in the group, was used. A diet giving a score of more than 3 was regarded as non-protective, between 1 and 1.5 as moderately protective, and under 1 as highly protective.

\section{CONTROLS}

South Indian diet was used as the basic reference diet and at frequent intervals throughout the experiments batches of eight rats were fed on unaltered South Indian diet to constitute a control group. Altogether there were 152 rats in this group. The results are shown in Table 1.

\section{COMPOSITION OF GROUPS}

The experiments were done in four groups:

Group 1 This was a continuation of the experiments previously reported ${ }^{5}$ comparing South Indian diet with Punjabi diet, plus additional experiments studying the effect of removing the pulses and/or vegetables from Punjabi diet.

Group 2 The effect was assessed of adding groups of food substances from Punjabi diet and items of food from the diets of the Kond and Gond tribes to South Indian diet.

Group 3 The effect was ascertained of adding a variety of other foodstuffs from high and low incidence areas to South Indian diet and also certain food substances available in both areas.

Group 4 The effect was assessed in a miscellaneous group of adding unrefined and refined wheat and unmilled rice, skimmed milk and whole cream milk powder, and also various oils to South Indian diet.

\section{DETAILS OF DIETS}

Group 1: Punjabi and South Indian diets

The composition of the Punjabi and South Indian diets expressed as percentage by weight was as follows:

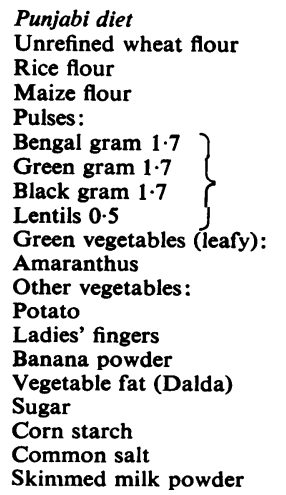


Apart from some of the earlier experiments, the foodstuffs were given uncooked. The constituents of the diet were evenly mixed into a mash with boiling water. The rats showed no tendency to be selective in their eating. Although whole cream milk and its products feature in Punjabi diet it was decided to use skimmed milk powder in both diets to reduce the number of variables.

\section{Group 2: Additives to South Indian diet from Punjabi,} Kond, and Gond diets

(a) From Punjabi diet Groups of substances:
1. Pulses

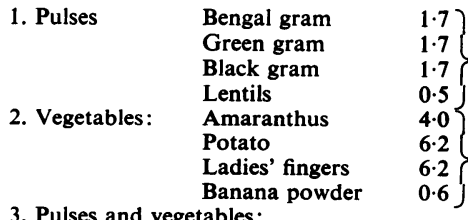

$5 \cdot 6 \%$

Pulses and vegetables:

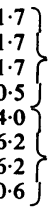

$17 \cdot 0 \%$

1 and 2 above in combination

4. Wheat (unrefined) $41 \cdot 2 \%$ plus pulses and vegetables as above

(b) From the Kond tribe's diet
1. Kahari (Querry)
2. Horse gram
$5 \%$

(c) From Gond tribe's diet

1. Sava

2. Kutki

$78.5 \%$ (in place of rice) $78.5 \%$ (in place of rice)

Table 2 Foodstuffs added to South Indian diet

\begin{tabular}{|c|c|c|c|c|c|c|c|c|}
\hline \multirow{2}{*}{$\begin{array}{l}\text { Corresponding } \\
\text { control group }\end{array}$} & \multirow[t]{2}{*}{ Additives } & \multirow[t]{2}{*}{$\%$} & \multirow{2}{*}{$\begin{array}{l}\text { Total no. } \\
\text { of rats }\end{array}$} & \multicolumn{5}{|c|}{ Rumenal ulcers } \\
\hline & & & & $\begin{array}{l}\text { No. of rats } \\
\text { with ulcers }\end{array}$ & $\begin{array}{l}\text { Total no. } \\
\text { of ulcers }\end{array}$ & Large ulcers & Perforations & Ulcer score \\
\hline No. & $\begin{array}{l}\text { Group } 3 \\
\text { From low incidence areas } \\
\text { Punjab }\end{array}$ & & & & & & & \\
\hline 13 & Bengal gram & 5 & 8 & 8 & 16 & 3 & 2 & 2 \\
\hline 13 & Green gram & 5 & 8 & 5 & 12 & 2 & 1 & 1.5 \\
\hline 13 & Pulses Black gram & 5 & 8 & 6 & 13 & 3 & 0 & 1.625 \\
\hline 17 & $\int$ Red gram & 5 & 8 & 8 & 24 & 7 & 3 & $3 \cdot 0$ \\
\hline 11 & $\begin{array}{l}\text { Vegetab̆les } \\
\text { Ladies' fingers (mucilage) } \\
\text { Chamarajnagar area }\end{array}$ & 10 & 8 & 5 & 5 & 1 & $\mathbf{0}$ & 0.625 \\
\hline 7 & $\begin{array}{l}\text { Millet (ragi) } \\
\text { From high incidence areas } \\
\text { South India }\end{array}$ & $60 *$ & 8 & 7 & 10 & 3 & 1 & $1 \cdot 25$ \\
\hline 16 & Cassava & $60^{*}$ & $\begin{array}{l}8 \\
8 \\
8\end{array}$ & $\begin{array}{l}8 \\
8 \\
8\end{array}$ & $\begin{array}{l}42 \\
41 \\
40\end{array}$ & $\begin{array}{l}10 \\
10 \\
13\end{array}$ & $\begin{array}{l}4 \\
3 \\
4\end{array}$ & $\begin{array}{l}5 \cdot 25 \\
5 \cdot 12 \\
5 \cdot 0\end{array}$ \\
\hline 17 & $\begin{array}{l}\text { Sorghum vulgare } \\
\text { Vegetables }\end{array}$ & $60 *$ & 8 & 7 & 16 & 5 & 1 & 2.0 \\
\hline Nil & Amaranthus (dried) & 5 & $\begin{array}{l}8 \\
8\end{array}$ & $\begin{array}{l}8 \\
8\end{array}$ & $\begin{array}{l}25 \\
22\end{array}$ & $\begin{array}{r}10 \\
9\end{array}$ & $\begin{array}{l}4 \\
5\end{array}$ & $\begin{array}{l}3 \cdot 125 \\
2 \cdot 75\end{array}$ \\
\hline $\begin{array}{l}12 \\
14\end{array}$ & $\begin{array}{l}\text { Brinjal } \\
\text { Bananas }\end{array}$ & 5 & 8 & 8 & 26 & 3 & 1 & $3 \cdot 25$ \\
\hline & $\begin{array}{l}\text { Raw } \\
\text { Cooked }\end{array}$ & $\begin{array}{l}20^{*} \\
20^{*}\end{array}$ & $\begin{array}{l}8 \\
8\end{array}$ & $\begin{array}{l}8 \\
8\end{array}$ & $\begin{array}{l}22 \\
19\end{array}$ & $\begin{array}{l}4 \\
5\end{array}$ & $\begin{array}{l}3 \\
2\end{array}$ & $\begin{array}{l}2 \cdot 75 \\
2 \cdot 375\end{array}$ \\
\hline Nil & $\begin{array}{l}\text { Aravalli Range } \\
\text { Maize }\end{array}$ & & & & & & & \\
\hline & $\begin{array}{l}\text { Coarse } \\
\text { Refined }\end{array}$ & $\begin{array}{l}60 * \\
60^{*}\end{array}$ & $\begin{array}{l}8 \\
8\end{array}$ & $\begin{array}{l}6 \\
8\end{array}$ & $\begin{array}{l}25 \\
30\end{array}$ & $\begin{array}{l}6 \\
7\end{array}$ & $\begin{array}{l}1 \\
3\end{array}$ & $\begin{array}{l}3 \cdot 125 \\
3 \cdot 75\end{array}$ \\
\hline Available all a & eas & & & & & & & \\
\hline Nil & $\begin{array}{l}\text { Vegetables } \\
\text { Cabbage }\end{array}$ & & & & & & & \\
\hline & Dried & 5 & 8 & 4 & 6 & 2 & $\mathbf{0}$ & 0.75 \\
\hline & Fresh & 5 & 8 & 6 & 8 & 2 & 0 & 1.00 \\
\hline 17 & $\begin{array}{l}\text { Spinach } \\
\text { Soya bean }\end{array}$ & 5 & 8 & 3 & 7 & 3 & $\mathbf{0}$ & 0.875 \\
\hline 5 & Cake & 10 & 8 & 4 & 7 & 1 & 0 & 0.875 \\
\hline 13 & Flour & 5 & 8 & 6 & 10 & 3 & 1 & $1 \cdot 25$ \\
\hline Nil & Sugar & 10 & 8 & 8 & 32 & 6 & 2 & 4.0 \\
\hline & Group 4 & & & & & & & \\
\hline 17 & Unrefined wheat & 78.5* & 8 & 4 & 6 & 1 & 0 & 0.75 \\
\hline & Refined wheat & $78 \cdot 5^{*}$ & 8 & 8 & 22 & 8 & 1 & 2.75 \\
\hline Nil & Unmilled rice & $78 \cdot 5^{*}$ & $\begin{array}{l}8 \\
8\end{array}$ & $\begin{array}{l}3 \\
2\end{array}$ & 8 & 0 & 0 & $\begin{array}{l}1.0 \\
1.375\end{array}$ \\
\hline & Milk powder & & & & & & & $1 \cdot 375$ \\
\hline Nil & Full çream & 1 & 8 & 6 & 9 & 1 & 1 & $1 \cdot 125$ \\
\hline Nil & $\begin{array}{l}\text { Skimmed } \\
\text { Oils }\end{array}$ & 1 & 8 & 8 & 19 & 5 & 1 & 2.375 \\
\hline 13 & Soya bean & $0.1 \mathrm{ml}$ & 8 & 2 & 4 & 0 & 0 & 0.5 \\
\hline 7 & Ragi & $0.1 \mathrm{ml}$ & 8 & 7 & 7 & 3 & 1 & 0.875 \\
\hline 7 & Cowpea & & 8 & 7 & 13 & 4 & 2 & 1.625 \\
\hline Nil & Cotton seed & & 8 & 8 & 18 & 4 & 2 & $2 \cdot 25$ \\
\hline
\end{tabular}

In place of an equivalent amount of polished rice. 
SOUTH INDIAN $\vee$ PUNJABI DIET

SOUTH INDIAN cooked

uncooked

$(1,2,3)$

PUNJABI DIET

cooked

uncooked

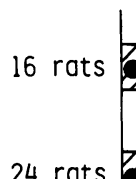

24 rats

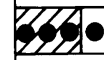

10
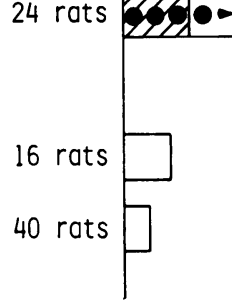

$\%$

Ulcer Rats with

score ulcers

$4.25 \quad 100$

$4.47 \quad 100$

$0.87 \quad 56$

$0.47 \quad 37.5$
Fig. 2 Comparison of the effect of two weeks' prefeeding with South Indian and Punjabi diet on rumenal ulceration after pyloric ligation. Key to Figures:

Blank: ulcer score. Hatched area: percentage of large ulcers $\bullet$ : number of perforations per batch of eight rats. (The number in parentheses shows the number of the corresponding control group).
Groups 3 and 4-Details of these groups are given in Table 2.

\section{Results}

GROUP 1 : PUNJABI V. SOUTH INDIAN DIETS

Figure 2 shows that Punjabi diet conferred a marked degree of protection when compared with South Indian diet. When the food is cooked there is no significant change in the number of ulcers with either diet.

Figure 3 shows that removal of the vegetables and pulses from Punjabi diet either singly or in combination removed its protective effect.

PUNJABI DIET

PUNJABI DIET

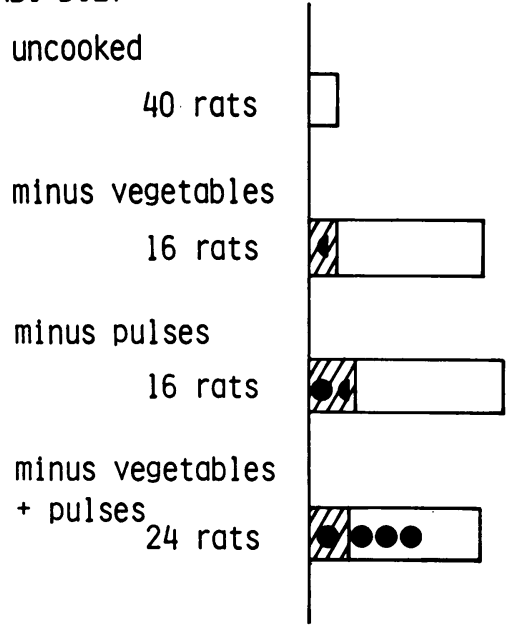

GROUP 2: ADDITION OF SUBSTANCES FROM PUNJABI DIET TO SOUTH INDIAN DIET Figure 4 shows that, although adding the groups of pulses or vegetables alone did not give significant protection, combining them gave moderate protection, and adding $41.2 \%$ unrefined wheat gave marked protection.

ADDITION OF SUBSTANCES FROM KOND TRIBE'S DIET AND FROM GOND TRIBE'S DIET TO SOUTH INDIAN DIET

Horse gram from the Kond tribe's diet was highly protective, and the cereal Kahari (querry) modera-

$\begin{array}{cc}\% \\ \text { Ulcer } & \begin{array}{c}\text { Rats with } \\ \text { ulcers }\end{array}\end{array}$
$0.47 \quad 37.5$

$2.7 \quad 100$
Fig. 3 The effect of removing pulses and/or vegetables from Punjabi diet on rumenal ulceration after pyloric ligation.

$3.0 \quad 94$
$2.625 \quad 87.5$ 


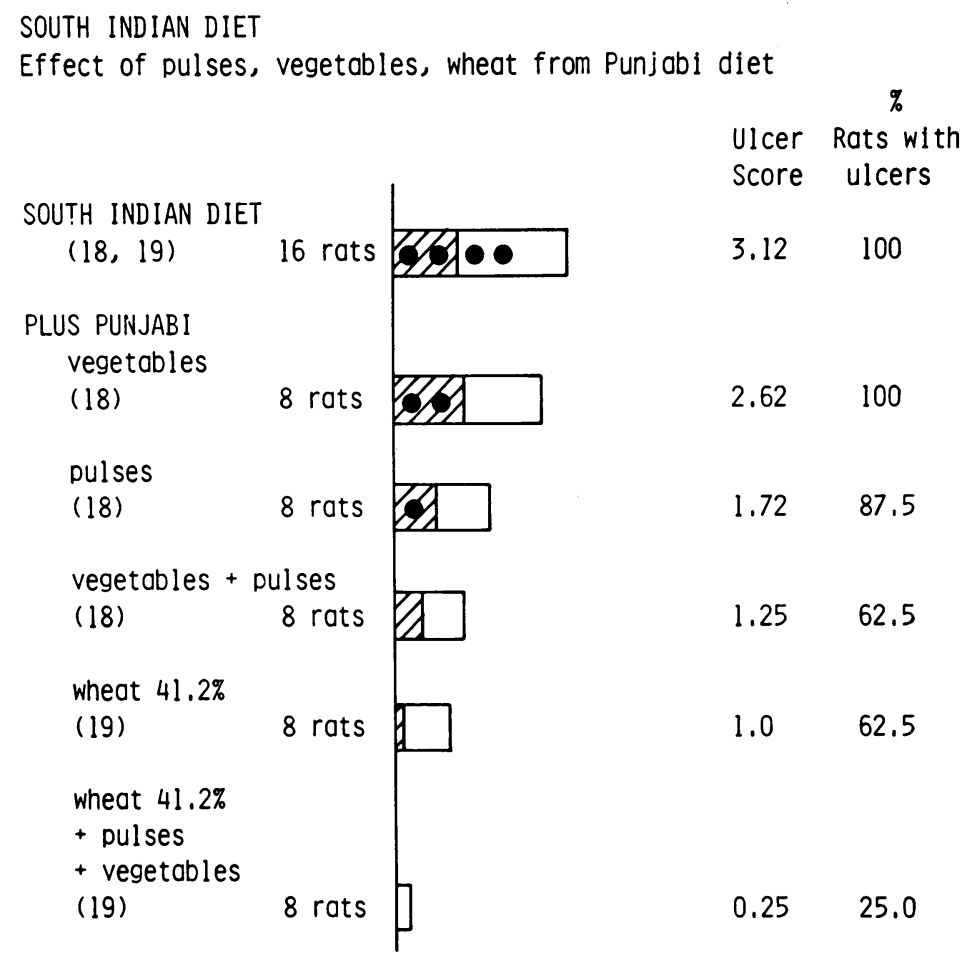

Fig. 4 The effect of adding vegetables and/or pulses, and of wheat to South Indian diet on rumenal ulceration after pyloric ligation.

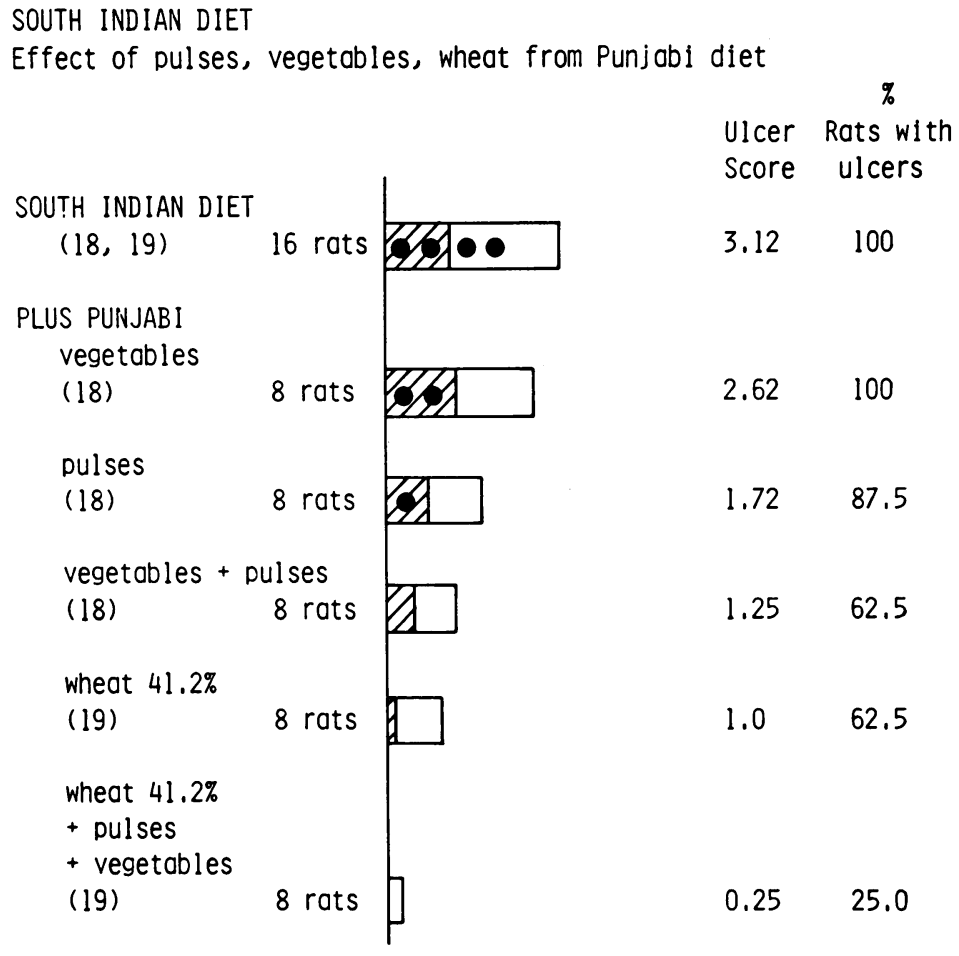

tely protective. Bengal gram was not protective. These were given at the $5 \%$ level.

The millets sava and kutki from the Gond tribe's diet were highly protective at the $78 \cdot 5 \%$ level.

GROUP 3 : OTHER FOODSTUFFS ADDED TO SOUTH INDIAN DIET

From low incidence areas of duodenal ulceration From the Punjab The pulses green gram and black gram were moderately protective. Bengal gram and red gram (Kabuli sanna) gave no protection.

The mucilage from ladies' fingers was protective.

From the Chamarajnagar area of Mysore The millet ragi was moderately protective.

From high incidence areas of duodenal ulceration From South India Cassava and sorghum vulgare were non-protective. (Cassava increased the ulcer
Fig. 5 The effect of adding foodstuffs from Kond diet to South Indian diet on rumenal ulceration after pyloric ligation. 
SOUTH INDIAN DIET

Effect of millets from Gondi diet

\section{$\%$}

Ulcer Rats with

Score ulcers

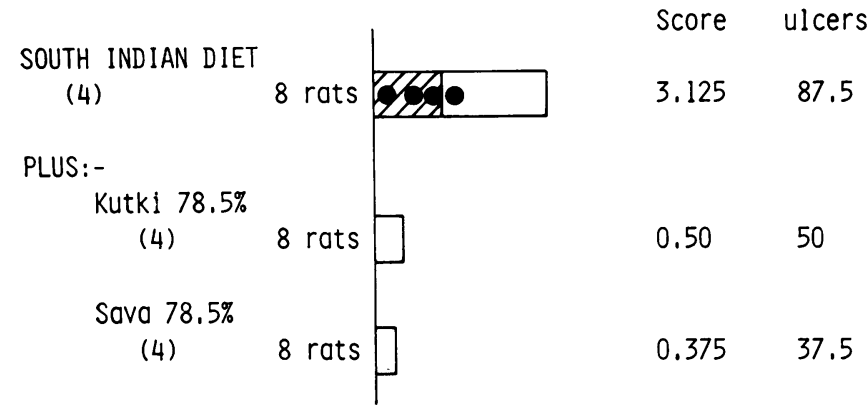

Table 3 Pylorus ligation (prefeeding)

\begin{tabular}{|c|c|c|c|}
\hline & No protection & $\begin{array}{l}\text { Moderately } \\
\text { protective }\end{array}$ & $\begin{array}{l}\text { Highly } \\
\text { protective }\end{array}$ \\
\hline Staple foods & $\begin{array}{l}\text { Wheat_refined } \\
\text { Rice_polished* } \\
\text { Maize_- } \\
\text { unrefined* } \\
\text { cornflour* } \\
\text { Cassava* } \\
\text { Sugar }\end{array}$ & $\begin{array}{l}\text { Rice-unmilled } \\
\text { Kahari (Querry)† }\end{array}$ & $\begin{array}{l}\text { Wheat- } \\
\text { unrefined } \dagger\end{array}$ \\
\hline Millets & Cholam* & Ragit & $\begin{array}{l}\text { Sava } \dagger \\
\text { Kutki } \dagger\end{array}$ \\
\hline Pulses & $\begin{array}{l}\text { Turdhal* } \\
\text { Bengal gram } \\
\text { Kabuli sanna }\end{array}$ & $\begin{array}{l}\text { Green gram } \dagger \\
\text { Black gram } \dagger\end{array}$ & Horse gram $†$ \\
\hline Beans & & & Soya bean \\
\hline Green vegetables & $\begin{array}{l}\text { Amaranthus* } \\
\text { Lettuce }\end{array}$ & & $\begin{array}{l}\text { Cabbage } \\
\text { Spinach }\end{array}$ \\
\hline $\begin{array}{l}\text { Other } \\
\text { vegetables }\end{array}$ & $\begin{array}{l}\text { Brinjal* } \\
\text { Potato } \\
\text { Banana* }\end{array}$ & & Ladies' fingers $\dagger$ \\
\hline Milk powder & Skimmed & Full cream $†$ & \\
\hline Oils & $\begin{array}{l}\text { Groundnut* } \\
\text { Cotton seed* } \\
\text { Cowpea }\end{array}$ & & $\begin{array}{l}\text { Soya } \\
\text { Ragi }\end{array}$ \\
\hline
\end{tabular}

-Foods from high incidence areas.

†Foods are from low incidence areas. score.) The vegetables amaranthus, brinjal, and bananas (raw and cooked) were non-protective.

From the Aravalli range of Rajasthan Unrefined and refined maize (cornflour) were non-protective. Available in high and low incidence areas The vegetables cabbage (dried and fresh) and spinach were highly protective. Soya bean cake was highly protective at the $10 \%$ level and soya bean flour moderately protective at the $5 \%$ level. Sugar was non-protective and increased the ulcer score.

\section{GROUP 4 : UNREFINED AND REFINED WHEAT} AND UNMILLED RICE

Unrefined wheat was highly protective and refined wheat was non-protective. Unmilled rice was moderately protective.

Full cream and skimmed milk powder

Full cream milk powder gave moderate protection and skimmed milk powder gave no protection.

Various oils

Ragi oil and soya bean oil were highly protective, but

Table 4 Ether extracts

\begin{tabular}{|c|c|c|c|c|c|c|c|c|}
\hline \multirow{2}{*}{$\begin{array}{l}\text { Corresponding } \\
\text { control group } \\
\text { (no.) }\end{array}$} & \multirow{2}{*}{\multicolumn{2}{|c|}{$\begin{array}{l}\text { South Indian diet } \\
\text { plus ether extract } \\
\text { (equivalent to: } \mathrm{mg} \text { ) }\end{array}$}} & \multirow{2}{*}{$\begin{array}{l}\text { Total no. } \\
\text { of rats }\end{array}$} & \multicolumn{5}{|c|}{ Rumenal ulcers } \\
\hline & & & & $\begin{array}{l}\text { No. of rats } \\
\text { with ulcers }\end{array}$ & $\begin{array}{l}\text { Total no. } \\
\text { of ulcers }\end{array}$ & Large ulcers & Perforations & Ulcer score \\
\hline 10 & $\begin{array}{l}\text { Millets } \\
\text { Sava } \\
\text { Kutki } \\
\text { Horse gram }\end{array}$ & $\begin{array}{l}220 \\
200\end{array}$ & $\begin{array}{l}8 \\
8\end{array}$ & $\begin{array}{l}7 \\
5\end{array}$ & $\begin{array}{r}12 \\
9\end{array}$ & $\begin{array}{l}3 \\
3\end{array}$ & $\begin{array}{l}0 \\
1\end{array}$ & $\begin{array}{l}1 \cdot 5 \\
1 \cdot 125\end{array}$ \\
\hline 6,9 & Orally & $4 \cdot 0$ & $\begin{array}{l}8 \\
8\end{array}$ & 1 & $\begin{array}{l}1 \\
2\end{array}$ & $\begin{array}{l}0 \\
0\end{array}$ & $\begin{array}{l}0 \\
0\end{array}$ & $\begin{array}{l}0 \cdot 125 \\
0 \cdot 25\end{array}$ \\
\hline 11,12 & Intramuscularly & $2 \cdot 5$ & $\begin{array}{l}8 \\
8\end{array}$ & $\begin{array}{l}4 \\
3\end{array}$ & $\begin{array}{l}5 \\
3\end{array}$ & $\begin{array}{l}1 \\
0\end{array}$ & $\begin{array}{l}\mathbf{0} \\
\mathbf{0}\end{array}$ & $\begin{array}{l}0.625 \\
0.375\end{array}$ \\
\hline 6,7 & $\begin{array}{l}\text { Orally: ether fract } \\
\text { (equivalent to } 5 \mathrm{~g}\end{array}$ & $\begin{array}{l}\text { ton from alcoholic extract } \\
\% \text { horse gram in diet) }\end{array}$ & $\begin{array}{l}8 \\
8 \\
8\end{array}$ & 2 & $\begin{array}{l}3 \\
3\end{array}$ & $\begin{array}{l}0 \\
1\end{array}$ & $\begin{array}{l}0 \\
1\end{array}$ & $\begin{array}{l}0.375 \\
0.375\end{array}$ \\
\hline
\end{tabular}


groundnut, cowpea, and cotton seed oil gave no protection.

The findings are summarised in Table 3.

\section{Histology}

The sections of the mucosa and rumen in the rats with a high ulcer score showed multiple erosions and infiltration with inflammatory cells. The mucosa and rumenal epithelium of those with a low score were much thicker and normal looking. The mucosal cells were also rich in mucus, whereas those with a high ulcer score were almost devoid of mucus.

\section{Discussion}

The results show a good correlation with the geographical distribution of duodenal ulcer in India and suggest that many of the food substances peculiar to the low incidence areas may contain a protective factor. The protective effect of Punjabi diet would appear to be an accumulative effect and a result of the combination of several substances each with a moderate protective action: black gram, green gram, ladies' fingers, whole cream milk, plus unrefined wheat. (The findings with regard to wheat are discussed below.) In the Konds' diet, kahari is moderately protective and horse gram is highly protective. The millets, sava and kutki, in the Gonds' diet are protective. Ragi, the principal staple food of the low incidence area south of Mysore, is also moderately protective. Sorghum vulgare, the staple diet in some high ulcer incidence areas, is non-protective, and cassava, which features in the very high ulcer incidence area of Kerala, seems to be almost ulcerogenic.

The possibility of the presence of protective factors against peptic ulceration in naturally occurring food substances is supported by the action of carbenoxolone and also the deglycyrrhizinated fractions obtained from liquorice. Twenty years ago Cheney ${ }^{6-8}$ showed that pre-feeding with several foodstuffs (cabbage, butter, egg yolk) conferred protection against experimental peptic ulceration in several animal models. Raw cabbage ${ }^{6-9}$ was highly protective but its action varied with season and storage. The protective factor was thermolabile and destroyed by cooking. It was also liposoluble. It was from the lipid fraction of cabbage that Adami $^{10-12}$ eventually developed gefarnate, which has healing properties in peptic ulceration. Gefarnate was found to act systemically whether given orally or parenterally, whereas the action of carbenoxolone is topical.

The findings in this series of experiments support those of Cheney in confirming the protective actions of cabbage and whole cream milk even in powder form. The natural oils occurring in soya bean and ragi were protective. Ether extracts were made from some of the other foodstuffs which had proved protective-sava, kutki, and horse gram. The results are shown in Table 4. All showed some protection. This was most marked with horse gram, which was active in very small amounts when given either orally or by intramuscular injection for two weeks before pyloric ligation. These results and those of other fractionation experiments are being reported separately.

\section{UNREFINED WHEAT}

The findings with regard to unrefined wheat require further comment. At the $41.2 \%$ level and $78.5 \%$ it was protective when added to South Indian diet. It has yet to be explained why Punjabi diet deprived of its pulses and vegetables was non-protective, even though it contained unrefined wheat (after removal of the pulses and vegetables the proportion of unrefined wheat rises to $53 \%$ ). It is postulated that the remaining maize, cornflour, and sugar may have an adverse non-protective effect. Both cornflour and sugar (Table 2) increased the ulcer score in a similar way to cassava when added to South Indian diet.

\section{Conclusion}

The overall findings support the hypothesis that there may be a dietary basis to account for the distribution of duodenal ulcer in India. It is postulated that, while in any community there are people with increased susceptibility to duodenal ulceration, the absence or presence of protective factors in the diet may determine whether or not they develop actual ulceration. The findings with regard to unrefined rice and wheat, and to sugar, lend support to Cleave's observations about the distribution and changing incidence of peptic ulcer. ${ }^{15-16}$ The evidence obtained from pyloric ligated rats is being substantiated using other experimental models, and further fractionation is being done to identify the active principles. The hypothesis, if valid, needs to fit in with the geographical distribution and changes in incidence in other countries. Already it seems to fit in with the distribution in Java where duodenal ulcer is uncommon in the areas where soya bean is eaten with rice (personal communication). It may fit in with the Pacific islands where duodenal ulcers seem to occur only in the areas where taro is the staple food (taro is similar to cassava). ${ }^{17-18}$ It may also fit in with the changing incidence and dietary habits in the United Kingdom with the varying consumption of refined carbohydrate, fresh vege- 
tables, and milk. At the moment, however, no definite pattern has emerged from a study of diets in the high and low incidence areas of duodenal ulceration in Africa, ${ }^{19}$ but much more information is still required.

If it is substantiated that certain foods do contain protective factors it will be important to determine whether the same factor may be present throughout and whether it is a lipid or a liposoluble substance. In the same way as Malhotra found that Punjabi diet prevented patients with healed duodenal ulcer from getting relapses, so it may prove possible that, at some time in the future, relapses may be prevented by taking a small dose of 'protective factor' and that horse gram (Dolichos biflorus) may prove to be a rich source of the factor. The same factor may be of use also in the treatment of peptic ulcer as a cytoprotective agent, perhaps in combination with $\mathrm{H}_{2}$ antagonists.

\section{Statistical analysis}

A probability plot of the 60 groups of eight rats referred to in Tables 1, 2, 4 shows that the data fall into two main groups, those with a total score of less than 16-that is, average score per rat of 2-and those with a score of 16 or more. This suggests two groups of diets, the protective and the non-protective. Examination of the points at the extremities suggests oral horse gram to be very protective and cassava to be almost ulcerogenic.

The authors wish to thank Dr B L Amla, recent Director of the Central Food Technological Research Institute of Mysore, for his encouragement and permission to do pylorus ligation experiments in the Institute's laboratories. We should like to thank also Mr D Machin, Lecturer in Medical Statistics, University of Southampton, for the painstaking care which he has taken over the statistical analysis.

\section{References}

${ }^{1}$ Tovey FI. Peptic ulcer in India and Bangladesh. Gut $1979 ; 20$ : 329-47.
${ }^{2}$ Malhotra SL. A comparison of unrefined wheat and rice diets in the management of duodenal ulcer. Postgrad Med J 1978; 54: 6-9.

${ }^{3}$ Lee YH, Bianchi RG. Use of experimental peptic ulcer models for drug screening. In: Pfeiffer CJ, Roth JLA, eds. Peptic ulcer. Philadelphia: Lippincott, 1971: 219-348.

${ }^{4}$ Shay H, Gruenstein H, Siplet H, Komarov SA. Protection of gastric mucosa of the rat against ulceration by prefeeding with protein hydrolysate. Proc Soc Exp Biol Med 1948; 69: 369-73.

${ }^{5}$ Jayaraj AP, Tovey FI, Clark CG. The possibility of dietary protective factors in duodenal ulcer II. An investigation into the effect of prefeeding with different diets and of instillation of foodstuffs into the stomach on the incidence of ulcers in pylorus-ligated rats. Postgrad Med J 1976; 52: 640-4.

${ }^{6}$ Cheney G. Anti-peptic ulcer dietary factor. $\mathrm{J} \mathrm{Am}$ Dietetic Assoc 1950; 26: 668-72.

${ }^{7}$ Cheney G. The nature of the anti-peptic ulcer dietary factor. Stanford Med Bull 1950; 8: 144-61.

${ }^{8}$ Cheney G. Vitamin U therapy of peptic ulcer. California Med 1952; 77: 248-52.

${ }^{9}$ Singh GB, Zaidi SH, Bajpal RP. Effect of Brassica oleracea var capitata in the prevention and healing of experimental peptic ulceration. Indian J Med Res 1962; 50: 741-9.

${ }^{10}$ Adami E. Richerch sperimentale sur gattone antiulcera. Att Soc Lombard Sci Med Biol 1955; 10: 60-4.

${ }^{11}$ Adami E. A new class of drugs active in gastro-duodenal ulcers. Clinica Europa 9 (typescript only available).

${ }^{12}$ Adami E, Marazzi-Uberti E, Turba C. Pharmacological research on Gefarnate, a new synthetic isoprenoid with an anti ulcer action. Arch Int Pharmacodyn Ther 1964; 147: 113-45.

${ }^{13}$ Wissmer BAL, Adami E. A new way in ulcer therapy? Curr Ther Res 1965; 7: 474-82.

${ }^{14}$ Tovey FI, Jayaraj AP, Clark CG. The possibility of dietary protective factors in duodenal ulcer. Postgrad Med J 1975; 51 : 366-72.

${ }^{15}$ Cleave TL. 1962 Peptic ulcer. Bristol: Wright, 1962.

${ }^{16}$ Cleave TL. The saccharine disease. Bristol: Wright, 1974.

${ }^{17}$ MacLaurin BP, Wardill TEM, Faaiuaso ST, McKinnon M. Geographic distribution of peptic ulcer disease in Western Samoa. NZ Med J 1979; 89: 341-4.

${ }^{18}$ MacLaurin BP, Wardill TEM, Faaiuaso ST. Environmental aspects of peptic ulcer disease in Western Samoa. NZ Med J 1979; 89: 376-8.

${ }^{19}$ Tovey FI, Tunstall M. Duodenal ulcer in black population in Africa south of the Sahara. Gut 1975; 16: 564-76. 